\title{
Evaluation of the Antioxidant Properties, Fatty Acid Profile, Ash, Zinc, Crude Fiber and Pectin Content of Jamaican Sorrel (Hibiscus sabdariffa) and Citrus (Citrus sinensis) By-products from a Local Beverage Manufacturer \\ V Ranger, A Goldson-Barnaby, R Williams, C Bowen-Forbes, V Rattray, N James, I Thompson
}

\begin{abstract}
OBJECTIVE: Sorrel (Hibiscus sabdariffa) and citrus (Citrus sinensis) is widely utilized in the local beverage industry. By-products from this industry are mainly utilized as fodder and fertilizer but may be of commercial value. Phytochemical analyses were therefore performed on extracts from by-products of this industry. Extracts were evaluated for their antioxidant activity, total phenolics, fatty acid, crude fiber, pectin, ash and zinc content.
\end{abstract}

METHODS: Antioxidant activity and total phenolics were evaluated by a spectrophotometric assay. Lipids were Soxhlet extracted and characterized by nuclear magnetic resonance spectroscopy and gas chromatography/mass spectrometry. Zinc content was determined by atomic absorption spectroscopy. Crude fiber, pectin and ash were determined gravimetrically.

RESULTS: Extracts showed antioxidant activity with methanolic extracts containing higher levels of phenolics than ethyl acetate extracts. Lipids were a source of omega 6 and omega 9 fatty acids. Palmitoleic acid was also identified in citrus extracts. Palmitic acid is the major saturated fatty acid present. Based on the predicted iodine value, citrus lipid extracts are expected to be more stable to oxidation compared to sorrel extracts. Zinc analysis by atomic absorption spectroscopy revealed that sorrel extracts had higher levels of zinc (367.3 ppm) compared to citrus extracts (Zn $5.0 \mathrm{ppm})$. Extracts were a minor source of pectin and crude fiber.

CONCLUSION: By-products from the local beverage industry may be considered for use in food and nutraceutical applications. They are a source of antioxidants, essential fatty acids, zinc and crude fiber.

Keywords: Antioxidant activity, citrus sinensis, hibiscus sabdariffa, fatty acid, phenolics, zinc

From: Department of Chemistry, The University of the West Indies, Mona, Jamaica.

Correspondence: Dr A Goldson-Barnaby, Department of Chemistry, Faculty of Science and Technology, The University of the West Indies, 2 Plymouth Crescent, Mona, Kingston 7

Jamaica, Fax: (876) 977-1835, email: andrea.goldson03@uwimona.edu.jm 


\section{INTRODUCTION}

Hibiscus sabdariffa is an annual herb or shrub popularly known as roselle or sorrel belonging to the Malvaceae family. It is native to India and Malaysia, where it is cultivated. The plant is also grown in Jamaica, South America and Africa. The calyx of $H$. sabdariffa is widely used as food, in jams, jellies, pickles, juice drinks, wine and as medicinal syrups (1). In Jamaica and some countries in Africa, the sorrel calyx is used to produce a traditional drink. In Nigeria the drink is referred to as "zoborodo". The intense red colour of the calyx is due to the presence of anthocyanins. The major anthocyanins present are delphinidin 3-sambubioside and cyanidin 3sambubioside (2). In addition to anthocyanins, other components present include alkaloids, flavonoids, saponins, steroids, sterols and tannins (2). Sorrel has powerful antioxidant properties (3) which helps to lower elevated blood pressure, bad cholesterol and detoxifies the body. Sorrel extracts have also been reported as possessing antimicrobial activity and is active against $E$ coli 0157:H7 a significant cause of foodborne and water borne disease (4).

Citrus sinensis is widely cultivated and is eaten fresh or processed into jams, juices and marmalades. It belongs to the family Rutaceae. The peel of the fruit is rich in flavonoids, alkaloids, saponins, tannins, triterpenoids, phytosterols and steroids possessing medicinal properties such as antiviral, antibacterial and antioxidant activities $(5,6)$. The fruit is well known for its ascorbic acid content and antioxidant activity (7).

Hibiscus sabdariffa and Citrus sinensis are utilized in Jamaica's local beverage industry. This industry produces a considerable quantity of solid and liquid residue rich in soluble sugars, cellulose, hemicellulose, pectin and essential oils, which is considered as waste (8). The waste in most cases is spread on soil in areas adjacent to the production location, for its final use as a raw material in animal feed (9). Alternatively it may be burned. This method of handling waste 
produces highly polluted wastewater with high chemical and biological oxygen demands which can negatively affect the soil, the ground and superficial waters (10).

An alternative is to improve the management of these residues which may be used as a substrate for the production of value added compounds or in the production of organic fertilizers, pectin, bio-oils, essential oils and antioxidant compounds. These alternatives avoid environmental pollution and add value to these substances. Phytochemical analyses were therefore conducted on by-products from Jamaica's sorrel and citrus beverage industries.

\section{MATERIALS AND METHODS}

\section{Chemicals}

All chemicals were analytical grade. Folin-Ciocalteu reagent and 1,1-diphenyl-2-picrylhydrazyl were purchased from Sigma Aldrich (USA).

\section{Plant material}

Sorrel calyces and citrus (peel, pulp, seeds) by-products were obtained from a local juice processing plant in St Catherine, Jamaica. Samples were air dried at ambient temperature (4 days) and milled.

The 1,1-diphenyl-2-picrylhydrazyl (DPPH) radical scavenging assay

The DPPH assay was performed according to the method of Brand-Williams et al. (11). Concentrates were dissolved in methanol (1:3) and reacted $(1 \mathrm{~mL})$ with DPPH $(0.004 \%, 1 \mathrm{~mL}$, $30 \mathrm{~min}$ ). The absorbance was measured at $517 \mathrm{~nm}$ using a spectrophotometer (Thermo Fisher Scientific). A standard calibration curve was generated and the results expressed as $\mu \mathrm{mol} / \mathrm{g}$ gallic acid equivalents). 


\section{Total phenolic content assay}

The total phenolic content was determined by the Folin-Ciocalteu method, adopted and modified from Swain and Hillis (12). Samples were extracted with hexane, ethyl acetate and methanol. Extracts $(500 \mu \mathrm{L})$ were reacted with Folin-Ciocalteu reagent $(10 \% .2 .5 \mathrm{~mL})$ and $\mathrm{Na}_{2} \mathrm{CO}_{3}$ solution $(7.5 \%, 2 \mathrm{~mL})$. The solution was incubated at room temperature in the dark (30 min) and the absorbance measured at $760 \mathrm{~nm}$ using a spectrophotometer (Thermo Fisher Scientific). A standard calibration curve was generated and the results expressed as mg gallic acid/g.

\section{Lipid extraction}

Sorrel and citrus by-products were dried to constant weight $\left(60{ }^{\circ} \mathrm{C}, 8 \mathrm{~h}\right)$ and milled. Samples were lipid extracted with petroleum ether (bp 80-100 ${ }^{\circ} \mathrm{C}$, reflux) using a Soxhlet extractor. The resulting extract was concentrated in vacuo and the percent crude fat determined gravimetrically. Methylation of lipid extracts

Lipid extracts $(50 \mu \mathrm{L})$ were trans-methylated with methanol/acetyl chloride solution (13). The resulting fatty acid methyl esters (FAMEs) were determined by Gas Chromatography-Mass Spectrometry (GC-MS).

\section{Gas Chromatography-Mass Spectrometry}

Methylated samples $(1.0 \mu \mathrm{L})$ were chromatographed on a HP6890 series Gas Chromatograph interfaced with a HP5973 Mass Selective Detector. Constituent FAMEs were eluted in helium carrier gas (flow rate $1 \mathrm{~cm}^{3} / \mathrm{min}$ ) through a DB-VRX column $(20 \mathrm{~m}$ x $0.18 \mathrm{~mm}$ i.d. x $1.0 \mu \mathrm{m}$ film thickness, Agilent, Santa Clara, CA) in an oven programmed at $60{ }^{\circ} \mathrm{C}$ for $3 \mathrm{~min}$ and increased at a ramp rate of $10{ }^{\circ} \mathrm{C} / \mathrm{min}$ up to $250{ }^{\circ} \mathrm{C}$ for $15 \mathrm{~min}$. Samples were injected at $230{ }^{\circ} \mathrm{C}$ while the detector was maintained at $250{ }^{\circ} \mathrm{C}$. Constituents were identified with the National Institute of Standards and Technology (NIST) library of mass spectra and subsets (match quality $>80 \%$ ). 
${ }^{1} \mathrm{H}$ NMR and ${ }^{13} \mathrm{C}$ NMR Spectroscopy

${ }^{1} \mathrm{H}$ NMR and ${ }^{13} \mathrm{C}$ NMR characterization were performed on a Bruker BioSpin $200 \mathrm{MHz}$ at 200 MHz. Samples were run in deuterated chloroform $\left(\mathrm{CDCl}_{3}\right)$ at $25{ }^{\circ} \mathrm{C}$, with tetramethylsilane as the internal standard. In reporting ${ }^{1} \mathrm{H}$ NMR the following terms were used; singlet (s), doublet $(\mathrm{d})$, triplet $(\mathrm{t})$, multiplet $(\mathrm{m})$.

Iodine value

Iodine values were determined based on the FAME content and was calculated utilizing the formula:

Predicted $\mathrm{IV}=\mathrm{xC} 1+\mathrm{yC} 2+\mathrm{zC} 3$

$\mathrm{C} 1, \mathrm{C} 2$ and $\mathrm{C} 3$ corresponds to the relative percentage concentrations of unsaturated fatty acids (one, two and three double bonds, respectively) whereas $\mathrm{x}, \mathrm{y}$, and $\mathrm{z}$ are coefficients $(\mathrm{x}=1, \mathrm{y}=$ 1.5 , and $\mathrm{z}=2.62)(14)$.

\section{Atomic absorption spectroscopy}

Samples $(1.5 \mathrm{~g})$ were ashed in a muffle furnace $\left(600{ }^{\circ} \mathrm{C}\right.$ for $\left.1.5 \mathrm{~h}\right)$ and the resulting ash dissolved in $\mathrm{HCl}(10 \mathrm{~mL}, \mathrm{AR})$, diluted with deionized water and filtered. Measurements for zinc was made using a Perkin Elmer 2380 Flame Atomic Absorption Spectrophotometer system equipped with a zinc hollow cathode lamp. The following parameters were utilized: Lamp current $10 \mathrm{~mA}$, wavelength $214 \mathrm{~nm}$, slit width $0.0 .7 \mathrm{~nm}$ with flame type consisting of air/acetylene and stoichiometric fuel flow at 0.9 to $1.21 \mathrm{~min}^{-1}$. A stock solution of zinc was made and a standard calibration curve prepared. Results were expressed as ppm.

\section{Crude fiber}

Samples $(12 \mathrm{~g})$ were weighed and sulphuric acid $(0.1 \mathrm{M})$ added. The mixture was boiled (30 min) and then filtered. The resulting residue was rinsed with distilled water. Sodium hydroxide 
$(0.3 \mathrm{M})$ was added to the residue which was followed by boiling $(30 \mathrm{~min})$ and filtration. The residue was washed with water, hydrochloric acid (1\%) and ethanol. The insoluble matter was then transferred to a crucible and allowed to dry $\left(100^{\circ} \mathrm{C}\right)$ after which samples were ashed $(550$ ${ }^{\circ} \mathrm{C}, 2 \mathrm{~h}$ ) and the crude fiber content determined gravimetrically.

\section{Pectin content}

Samples $(50 \mathrm{~g})$ were suspended in deionized water $(400 \mathrm{~mL})$ and boiled $(1 \mathrm{~h})$. Extracts were filtered and sodium hydroxide (1 M) added. The solution was allowed to stand (24 h) after which acetic acid $(1 \mathrm{M})$ was added followed by calcium chloride $(0.5 \mathrm{M})$. The solution was then boiled and filtered. The resulting residue was dried $\left(105^{\circ} \mathrm{C}, 3 \mathrm{~h}\right)$ and the mass of pectin determined gravimetrically.

\section{RESULTS AND DISCUSSION}

\section{Antioxidant activity and total phenolics}

Free radicals are produced in cells continually forming an integral part of cellular function. Over production may lead to oxidative stress which can result in the development of chronic and degenerative diseases such as cancer, neurological disorders and rheumatoid arthritis (15). Antioxidants assist in preventing cell damage by limiting the formation of free radicals, acting as free radical scavengers and promoting their decomposition (16). Hibiscus sabdariffa and Citrus sinensis have gained attention for their antioxidant activity (17-19). Sorrel and citrus by-product extracts possessed similar antioxidant activities $(141.57 \mu \mathrm{mol} / \mathrm{g} \pm 5.27$ and $139.77 \mu \mathrm{mol} / \mathrm{g} \pm 4.81$ gallic acid equivalents, respectively) and may be utilized as a source of natural antioxidants. Flavones and glycosylated flavanones are the main phenolics contributing to the antioxidant activity of citrus extracts (19). Phenolics and anthocyanins are primarily responsible for the 
antioxidant activity of sorrel extracts (20). Citrus extracts contained higher levels of phenolics compared to sorrel extracts (Table 1). A study on 13 citrus species revealed that total phenolics was higher in the peel of the fruit (21). Naringin and neohesperidin have been identified as the major polyphenols in methanolic extracts of bitter orange peels; narirutin and hesperidin in sweet orange peels (22). The total phenolics in different citrus species ranges from $66.5-396.8 \mathrm{mg}$ gallic acid equivalents/g (21) while sorrel has been reported as containing a total phenolic content of $41.07 \mathrm{mg}$ gallic acid equivalent/g (23).

\section{Lipid analysis}

Citrus oil concentrates have been utilized commercially in a wide number of applications. These include their use for flavour and fragrances. D-Limonene has been identified as the major component present in the essential oil extracts of citrus (24). Less reported is the utilization of sorrel oil extracts. Sorrel seed oil (25) which is rich in linoleic acid and oleic acid has been investigated for its nutritional properties (26) and its potential as a source of biofuel (27). The oil is also a good source of the lipid soluble antioxidant gamma tocopherol (28). Currently there is no literature on the fatty acid composition of sorrel calyces. The lipid content of the sorrel and citrus by-product extracts were $3.15 \% \pm 1.22$ and $3.70 \% \pm 1.30$ respectively. Linoleic acid and oleic acid were identified as the major unsaturated fatty acids and palmitic acid, the major saturated fatty acid (Table 2). Palmitoleic acid (omega 7) was identified in small quantities in citrus by-product extracts. Macadamia oil is a good source of palmitoleic acid (29). Palmitoleic acid has shown lipid lowering and anti-inflammatory benefits and may be useful in the treatment of hypertriglyceridemia (30). The predicted iodine value, an indicator of the oil's stability to oxidation was higher in sorrel extracts compared to citrus extracts $(59 ; 49$, respectively) due to 
the higher levels of linoleic acid and oleic acid present. Citrus lipid extracts are therefore expected to be more stable to oxidative rancidity.

${ }^{1} \mathrm{H}$ and ${ }^{13} \mathrm{C}$ NMR spectroscopy

Lipid extracts are comprised predominantly of triacylglycerols. ${ }^{1} \mathrm{H}$ NMR spectroscopy of the crude citrus and sorrel lipid extracts revealed the presence of two doublet of doublets ( $\delta 4.14$ 4.30) and a multiplet ( $\delta 5.34)$ which are consistent with the protons of the glyceryl moiety of a triacylglycerol (Table 3). The bis allylic protons due to linoleic acid resonated as a singlet at $\delta$ 2.76. Olefinic protons were observed at $\delta 5.37 .{ }^{13} \mathrm{C}$ NMR data confirmed the presence of the glycerol backbone of the triacylglycerols with signals resonating at $\delta 62.0 \mathrm{ppm}(\alpha)$ and $\delta 68.9$ ppm ( $\beta)$. Unsaturation within fatty acid side chains due to the presence of linoleic acid and oleic acid were observed in the range of $\delta 129-130 \mathrm{ppm}(31)$.

Ash

Ash is the inorganic matter remaining after heating organic components in the presence of oxidizing agents. It indicates total mineral content. Citrus and sorrel samples contained $3.2 \% \pm$ 0.4 and $4.4 \% \pm 0.3$ ash, respectively. Values of $1.5 \%$ (32) and $4.8 \%$ (33) have been reported for orange peels and $6.5 \%$ (34) and $12.2 \%$ (35) for sorrel calyces from Nigeria. Higher percentage ash values are seen in edible wild plants from Turkey, with values ranging from 7.5 $\%$ to $18.5 \%$ for Tragopogon aureus Boiss and Urtica dioica L. respectively (36). Values of 1.03 $\%$ and $0.51 \%$ have been reported for Daucus carota and Lycopersicom esculentum respectively (37).

Zinc content

Zinc is an essential trace element which is necessary for human health and well-being. The role of zinc in the body is both structural and functional. It plays an important role in over 300 
enzymatic reactions participating in different aspects of intermediary metabolism (38). High amounts of zinc can be found in the brain. Metalloproteins containing zinc serve as neuromodulators and neurotransmitters (39). Severe zinc deficiency can lead to behavioural problems and mood disorders (40). Zinc is required for normal immune function (38) possesses antioxidant (41) and anti-inflammatory properties (42). The ability of zinc to retard oxidative processes has been recognized for several years (43). The mechanism is believed to be by protection of sulfhydryl groups against oxidation and inhibition of the production of reactive oxygen by transition metals (44). Zinc also plays a structural role in the bone matrix (38). Bone mineral is composed of hydroxyapatite crystals, which contains $\mathrm{Zn}$ complexed with fluoride (38). Sorrel extracts investigated contained higher concentrations of zinc (367.3 ppm) compared to citrus $(5.0 \mathrm{ppm})$ and may be considered a good source of zinc.

\section{Crude fiber}

Plants are a source of dietary fiber which plays an important role in decreasing the risk of various disorders such as diabetes, cardiovascular disease, diverticulosis and obesity (45). Dietary fiber may be classified as water soluble/less fermentable (cellulose, hemicellulose, lignin) or water insoluble/fermentable (pectin, gums and mucilages) (46) and is utilized in various foods such as baked products, beverages and meat products. The use of fiber in foods not only enhances its health benefits but also leads to changes in the sensorial and rheological properties of the food. Crude fiber which consists mainly of cellulose, hemicellulose and lignin was determined by sequential extraction with acid and base followed by ashing. The crude fiber content of sorrel and citrus by-products were $(4.16 \pm 0.36 \%$ and $3.94 \% \pm 0.32)$ respectively. Sorrel calyces from Nigeria have been reported as containing $8.5 \%$ crude fiber (34) and orange peels $2.7 \%$ (33). When compared with other fruits, the crude fiber content of citrus and sorrel by-products is 
higher than that reported for watermelon $(0.2 \%)$, mango $(0.7 \%)$ and pomegranate $(2.1 \%)$ but comparable to custard apple $(3.1 \%)$, dates $(3.7 \%)$ and guava $(5.2 \%)$ (47). The nutritional benefits of food fibers has led to the development of fiber rich products. Alternative and novel sources of dietary fiber continue to be investigated for use in food supplementation. Non traditional sources such as by products from food processing continue to be evaluated, for example, spent brewer's grain, seed hulls and corn stalks (48). Nassar et al. (49) suggested that $15 \%$ of orange peel and pulp could be incorporated as an ingredient in baked products, as they are a source of dietary fibre with bioactive components.

\section{Pectin}

Pectin is a major component of the primary cell walls of plants and encompasses a range of galacturonic acid-rich polysaccharides (50). The major neutral sugars of hydrolysed pectin are arabinose, galactose and rhamnose with galacturonic acid contents ranging from $63-64 \%$ (51). The Food and Agriculture Organization stipulates that pectin must contain at least $65 \%$ galacturonic acid. Pectin is widely used in the food industry due to its ability to form gels as well as the cosmetic and pharmaceutical industries. Commercial sources of pectin are traditionally from apple pomace and citrus peel. Recent research has identified passion fruit peels as containing high levels of pectin with yields of $10-20 \%$ being reported $(52 ; 53)$. Pectin extraction is normally performed with a diluted strong mineral acid solution or weak organic acids, for example citric acid $(52,54,55)$. Sorrel and citrus by-products from the current study were extracted with acetic acid. Small quantities of pectin (sorrel, $0.48 \% \pm 0.13$ and citrus 0.84 $\% \pm 0.10)$ were recovered from the samples investigated. This may be due to pectin losses during the juice extraction process. Improved extraction efficiencies have been reported with the use of ammonium oxalate. Pectin extracted from sorrel utilizing ammonium oxalate gave yields of 18.7 
$\%$ ammonium compared with hydrochloric extractions $(9.8 \%)(56) . \mathrm{pH}$ is also an important parameter in the extraction of pectin. Maximum pectin yields of $14.6 \%$ were obtained from passion fruit peel at a $\mathrm{pH}$ of 2 . Orange peels which contain $1.7 \%$ pectin on a dry weight basis and $15.9 \%$ on a wet weight basis (57) are traditionally used as a source of pectin.

Relevance and potential applications

By-products from the sorrel and citrus industry may be considered for use in nutraceuticals, food fortification and an ingredient of functional foods. They are a source of antioxidants, omega fatty acids, zinc and crude fiber. Sorrel calyx by-products could be utilized in fruit snack formulations and chutneys. In recent years there has been growing interest in natural antioxidants and colorants with consumers showing increased concerns over the use of chemically synthesized dyes and artificial antioxidants due to their suspected carcinogenic effects.

\section{CONCLUSION}

Agro processing by-products can be better managed and utilized for various commercial applications. The conversion of cellulosic biomass to useable product presents an opportunity to reduce greenhouse gas emission, reduce global warming and utilize the by-products arising from the food industry.

\section{ACKNOWLEDGEMENTS}

Technical assistance was provided by Mr Winston Chambers. 


\section{REFERENCES}

1. Cid-Ortega S, Guerrero-Beltrán JA. Roselle calyces (Hibiscus sabdariffa), an alternative to the food and beverages industries: a review. J Food Sci Technol. 2015 Nov; 52(11): 6859-69.

2. Obouayeba AP, Djyh NB, Diabate S, Djaman AJ, N'Guessan JD, Kone M, Kouakou TH. Phytochemical and antioxidant activity of roselle (Hibiscus sabdariffa L.) petal extracts. Res J Pharm Biol Chem Sci. 2014 Mar-Apr; 5(2):1453-65.

3. Mutai E, Sunkara R, Vizcarra J, Walker LT, Verghese M. Antioxidant, enzyme inhibitory and anti-obesity potential of sorrel calyx extracts in 3T3-L1 adipocytes. Food Nutr Sci. 2015 Apr; 6(5):452-65.

4. Fullerton M, Khatiwada J, Johnson JU, Davis S, Williams LL. Determination of antimicrobial activity of sorrel (Hibiscus sabdariffa) on Escherichia coli O157:H7 isolated from food, veterinary, and clinical samples. J Med Food. 2011 Sep; 14(9):950-6.

5. Lawal D, Bala JA, Aliyu SY, Huguma MA. Phytochemical screening and in vitro antibacterial studies of the ethanolic extract of Citrus sinensis (Linn.) peel against some clinical bacterial isolates. IJIAS. $2013 \mathrm{Feb}$; 2(2):138-45.

6. Hegazy AE, Ibrahium MI. Antioxidant activities of orange peel extracts. World Appl Sci J. 2012; 18(5):684-8.

7. Chatha SAS, Hussain AI, Asi MR, Majeed M, Iqbal HMN. Evaluation of antioxidant potential of citrus peel extracts. J Chem Soc Pak. 2011 Dec; 33(6):863-8.

8. Rezzadori K, Benedetti S, Amante ER. Proposals for the residues recovery: orange waste as raw material for new products. Food Bioprod Process. 2012 Oct; 90(4):606-14. 
9. Martin MA, Siles JA, Chica AF, Martín A. Biomethanization of orange peel waste. Bioresour Technol. 2010 Dec; 101(23):8993-9.

10. Braddock RJ. By-products of citrus fruit. Food Technol. 1995; 49(9):74-7.

11. Brand-Williams W, Cuvelier ME, Berset C. Use of a free radical method to evaluate antioxidant activity. LWT-Food Sci Technol. 1995; 28(1):25-30.

12. Swain T, Hillis WE. The phenolic constituents of Prunus domestica. I. The quantitative analysis of phenolic constituents. J Sci Food Agr. 1959 Jan; 10(1):63-8.

13. Masood A, Stark KD, Salem N Jr. A simplified and efficient method for the analysis of fatty acid methyl esters suitable for large clinical studies. J Lipid Res. 2005; Oct; 46(10):2299-305.

14. Kyriakidis NB, Katsiloulis T. Calculation of iodine value from measurements of fatty acid methyl esters of some oils: Comparison with the relevant American Oil Chemists Society method. J American Oil Chem Soc. 2000 Dec; 77(12):1235-8.

15. Pham-Huy LA, He H, Pham-Huy C. Free radicals, antioxidants in disease and health. Int J Biomed Sci. 2008 Jun; 4(2):89-96.

16. Young IS, Woodside JV. Antioxidants in health and disease. J Clin Pathol. 2001 Mar; 54(3):176-86.

17. Christian KR, Nair MG, Jackson JC. Antioxidant and cyclooxygenase inhibitory activity of sorrel (Hibiscus sabdariffa). J Food Compost Anal. 2006 Dec; 19(8):778-83.

18. Christian KR, Jackson JC. Changes in total phenolic and monomeric anthocyanin composition and antioxidant activity of three varieties of sorrel (Hibiscus sabdariffa) during maturity. J Food Compost Anal. 2009 Nov-Dec; 22(7-8):663-67. 
19. Bocco A, Cuvelier ME, Richard H, Berset, C. Antioxidant activity and phenolic composition of citrus peel and seed extracts. J Agr Food Chem. 1998 May 5; 46(6):212329.

20. Yang L, Gou Y, Zhao T, Zhao J, Li F, Zhang B and Wu X. Antioxidant capacity of extracts from calyx fruits of roselle (Hibiscus sabdariffa L.). Afr J Biotechnol. 2012 Feb 28; 11(17):4063-68.

21. Ghasemi K, Ghasemi Y, Ebrahimzadeh MA. Antioxidant activity, phenol and flavonoid contents of 13 citrus species peels and tissues. Pak J Pharm Sci. 2009 Jul; 22(3):277-81.

22. Sawalha SMS, Arráez-Román D, Segura-Carretero A, Fernández-Gutiérrez A. Quantification of main phenolic compounds in sweet and bitter orange peel using CEMS/MS. Food Chem. 2009 Aug;116(2):567-74.

23. Sirag N, Elhadi MM, Algaili AM, Hassan HM, Ohaj M. Determination of total phenolic content and antioxidant activity of Roselle (Hibiscus sabdariffa L.) calyx ethanolic extract. Stand Res J Pharm. 2014 Aug; 1(2):34-9.

24. Darjazi BB. Comparison of peel oil components of grapefruit and lime (Citrus sp.). Intl J Agri Crop Sci. 2013; 6(12):840-7.

25. Betiku E, Adepoju TF. Sorrel (Hibiscus sabdariffa) seed oil extraction optimization and quality characterization. American Chemical Science Journal 2013 Oct-Dec; 3(4):449-58.

26. Samy MS. Chemical and nutritional studies on roselle seeds (Hibiscus sabdariffa L.). Z Ernahrungswiss. 1980 Mar; 19(1):47-9.

27. Nakpong P, Wootthikanokkhan S. Roselle (Hibiscus sabdariffa L.) oil as an alternative feedstock for biodiesel production in Thailand. Fuel. 2010 Aug; 89(8):1806-11. 
28. Mohamed R, Fernández J, Pineda M, Aguilar M. Roselle (Hibiscus sabdariffa) Seed oil is a rich source of $\gamma$-tocopherol. J Food Sci. 2007 Apr; 72(3):S207-11.

29. Garg ML, Blake RJ, Wills RBH, Clayton EH. Macadamia nut consumption modulates favourably risk factors for coronary artery disease in hypercholesterolemic subjects. Lipids. 2007 Jun; 42(6):583-7.

30. Bernstein AM, Roizen MF, Martinez L. Purified palmitoleic acid for the reduction of high-sensitivity C-reactive protein and serum lipids: A double-blinded, randomized, placebo controlled study. J Clin Lipidol. 2014 Nov-Dec; 8(6):612-17.

31. Thoss V, Murphy PJ, Marriott R, Wilson T. Triacylglycerol composition of British bluebell (Hyacinthoides non-scripta) seed oil. RSC Adv. 2012; 2(12):5314-22.

32. Ververis C, Georghiou K, Danielidis D, Hatzinikolaou DG, Santas P, Santas R, Corleti V. Cellulose, hemicelluloses, lignin and ash content of some organic materials and their suitability for use as paper pulp supplements. Bioresour Technol. 2007 Jan; 98(2):296301.

33. Azam S, Khan Z, Ahmad B, Khan I, Ali J. Production of single cell protein from orange peels using Aspergillus niger and Saccharomyces cerevisiae. Global Journal of Biotechnology \& Biochemistry. 2014 Jan; 9(1):14-8.

34. Babalola SO, Babalola AO, Aworh OC. Compositional attributes of the calyces of roselle (Hibiscus sabdariffa L.). The Journal of Food Technology in Africa. 2001; 6(4):133-4.

35. Adanlawo IG, Ajibade VA. Nutritive value of the two varieties of roselle (Hibiscus sabdariffa) calyces soaked with wood ash. Pak J Nutr. 2006; 5(6):555-7.

36. Cakilcioglu U, Khatun S. Nitrate, moisture and ash contents of edible wild plants. J Cell \& Plant Sci. 2011; 2(1):1-5. 
37. Motegaonkar MB, Salunke SD. The ash and iron content of common vegetable grown in Latur District, India. Res J Recent Sci. 2012 April; 1(4):60-3.

38. Meunier N, O’Connor JM, Maiani G, Cashman KD, Secker DL, Ferry M, Roussel AM and Coudray C. Importance of zinc in the elderly: the ZENITH study. Eur J Clin Nutr. 2005; 59(2):S1-S4.

39. Harrison NL, Gibbsons SJ. $\mathrm{Zn}^{2+}$ : an endogenous modulator of ligand- and voltage-gated ion channels. Neuropharmacol. 1994 Aug; 33(8):935-52.

40. McLoughlin IJ, Hodge JS. Zn in depressive disorder. Acta Psychiatr Scand. 1990 Dec; $82(6): 451-3$.

41. Bray TM, Bettger WJ. The physiological role of zinc as an antioxidant. Free Radical Biol Med. 1990; 8(3):281-91.

42. Prasad AS. Zinc: An antioxidant and anti-inflammatory agent: Role of zinc in degenerative disorders of aging. J Trace Elem Med Biol. 2014 Oct; 28(4):364-71.

43. Powell SR. The antioxidant properties of zinc. J Nutr. 2000 May; 130(5S):1447S-54S.

44. Bettger WJ. Zinc and selenium, site specific vs general antioxidant. Can J Physiol Pharmacol. 1993 Sep; 71(9):721-4.

45. Lattimer JM, Haub MD. Effects of dietary fiber and its components on metabolic health. Nutrients. 2010 Dec; 2(12):1266-89.

46. Dhingra D, Michael M, Rajput H, and Patil RT. Dietary fibre in foods: a review. J Food Sci Technol. 2012 Jun; 49(3):255-66.

47. Ramulu P, Rao PU. Total, insoluble and soluble dietary fiber contents of Indian fruits. J Food Compost Anal. 2003 Dec; 16(6):677-85.

48. Katz F. Putting the function in functional food. Food Process. 1996; 57(2):56-8. 
49. Nassar AG, AbdEl-Hamied AA, El-Naggar EA. Effect of citrus by-products flour incorporation on chemical, rheological and organoleptic characteristics of biscuits. World J Agric Sci. 2008; 4:612-16.

50. Willats WG, McCartney L, Mackie W, Knox JP. Pectin: cell biology and prospects for functional analysis. Plant Mol Biol. 2001 Sep; 47(1-2):9-27.

51. Day A, Dasgupta PC, Sardar D. Pectic substances from mesta (Hibiscus cannabinus) and roselle (Hibiscus sabdariffa) plants. Curr Sci. 1983; 52(18):885-6.

52. Pinheiro ER, Silva IMDA, Gonzaga LV, Amante ER, Teófilo RF, Ferreira MMC, Amboni RDMC. Optimization of extraction of high-ester pectin from passion fruit peel (Passiflora edulis Flavicarpa) with citric acid by using response surface methodology. Bioresour Technol. 2008 Sep; 99(13):5561-6.

53. Seixas FL, Fukuda DL, Turbiani FRB, Garcia PS, Petkowicz CLO, Jagadevan S, Gimenes ML. Extraction of pectin from passion fruit peel (Passiflora edulis F. Flavicarpa) by microwave-induced heating. Food Hydrocoll. 2014 July; 38:186-92.

54. Minjares-Fuentas R, Femenia A, Garau MC, Meza-Velazquez JA, Simal S, Rossello C. Ultrasound-assisted extraction of pectins from grape pomace using citric acid: A response surface methodology approach. Carbohydr Polym. 2014 June 15; 106:179-89.

55. Kulkarni SG, Vijayanand P. Effect of extraction conditions on the quality characteristics of pectin from passion fruit peel (Passiflora edulis f. flavicarpa L.). LWT-Food Sci Technol. 2010 Sep; 43(7):1026-31.

56. Nazaruddin R, Noor Baiti AA, Foo SC, Tan YN, Ayob MK. Comparative chemical characteristics of hydrochloric acid- and ammonium oxalate-extracted pectin from roselle (Hibiscus sabdariffa L.) calyces. Int Food Res J. 2013 Jan; 20(1):281-4. 
57. Aina VO, Barau MM, Mamman OA, Zakari A, Haruna H, Hauwa Umar MS, Abba YB. Extraction and characterization of pectin from peels of lemon (Citrus limon), grape fruit (Citrus paradisi) and sweet orange (Citrus sinensis). Br J Clin Pharmacol. 2012 Dec; 3(6): 259-62. 
Table 1: Total phenolic content of citrus and sorrel by-product extracts expressed as gallic acid equivalents (GAE)

\begin{tabular}{lcc}
\hline Extraction solvent & Citrus extract $(\mathrm{mg} / \mathrm{g})$ & Sorrel extract $(\mathrm{mg} / \mathrm{g})$ \\
\hline Hexane & ND & $8.08 \pm 1.96$ \\
Ethyl Acetate & $63.08 \pm 8.53$ & $21.68 \pm 4.62$ \\
Methanol & $118.09 \pm 6.98$ & $33.14 \pm 2.38$
\end{tabular}

ND: Not detected

Table 2: Fatty acid profile of sorrel and citrus by-product extracts

\begin{tabular}{lccc}
\hline \multicolumn{1}{c}{ Fatty acid } & & Sorrel (\%) & Citrus (\%) \\
\hline Palmitic acid & C16:0 & $42.45 \pm 14.35$ & $32.94 \pm 7.40$ \\
Palmitoleic acid (omega 7) & C16:1 & ND & $0.74 \pm 0.07$ \\
Stearic acid & C18:0 & $7.64 \pm 2.32$ & $7.21 \pm 1.49$ \\
Oleic acid (omega 9) & C18:1 & $20.82 \pm 2.95$ & $18.24 \pm 0.80$ \\
Linoleic acid (omega 6) & C18:2 & $25.37 \pm 6.33$ & $19.90 \pm 12.79$
\end{tabular}

ND: Not detected 
Table 3: ${ }^{1} \mathrm{H}$ Nuclear magnetic resonance spectroscopy data of sorrel and citrus by-product extracts

\begin{tabular}{|c|c|c|c|}
\hline Proton & Functionality & $\begin{array}{l}\text { Sorrel } \\
\delta \text { ppm }\end{array}$ & $\begin{array}{l}\text { Citrus } \\
\delta \text { ppm }\end{array}$ \\
\hline $\mathrm{CH}_{3}$ & Terminal methyl & $0.86(\mathrm{~m})$ & $0.88(\mathrm{~m})$ \\
\hline $\mathrm{CH}_{2}$ & Methylene & $1.26(\mathrm{~s})$ & $1.25(\mathrm{~s})$ \\
\hline $\mathrm{CH}_{2}-\mathrm{CH}_{2}-\mathrm{COO}$ & All acyl chains & $1.61(\mathrm{~m})$ & $1.60(\mathrm{~m})$ \\
\hline $\mathrm{CH}_{2}-\mathrm{CH}=\mathrm{CH}$ & All unsaturated fatty acids & $2.05(\mathrm{~s})$ & $2.02(\mathrm{~m})$ \\
\hline \multirow[t]{2}{*}{$\mathrm{CH}_{2}-\mathrm{COO}$} & All acyl chains & $2.28(\mathrm{~s})$ & \\
\hline & & $2.35(\mathrm{~m})$ & $2.34(\mathrm{t})$ \\
\hline $\mathrm{C}=\mathrm{C}-\mathrm{CH}_{2}=\mathrm{C}$ & $\begin{array}{l}\text { Protons attached to bisallylic } \\
\text { carbon }\end{array}$ & $2.76(\mathrm{~s})$ & $2.76(\mathrm{~s})$ \\
\hline \multirow[t]{2}{*}{$\mathrm{CH}_{2} \mathrm{O}(\alpha)$} & Glycerol (triglycerides) & $4.14(\mathrm{dd})$ & $4.15(\mathrm{dd})$ \\
\hline & & $4.26(\mathrm{dd})$ & $4.30(\mathrm{dd})$ \\
\hline $\mathrm{CHO}(\beta)$ & Glycerol (triglycerides) & $5.34(\mathrm{~m})$ & $5.34(\mathrm{~m})$ \\
\hline $\mathrm{CH}=\mathrm{CH}$ & Olefinic protons & $5.37(\mathrm{~m})$ & $5.37(\mathrm{~m})$ \\
\hline $\mathrm{COOH}$ & Free Fatty acids & $7.27(\mathrm{~s})$ & $7.27(\mathrm{~s})$ \\
\hline
\end{tabular}

m: multiplet; s: singlet; dd: doublet of doublet, t: triplet 